\title{
Dilemmas and Pitfalls in Rubella Laboratory Diagnostics in Low Prevalence or Elimination Settings
}

\author{
Carmen L. Charlton, PhD, D(ABMM), FCCM ${ }^{1,2, *}$ \\ Alberto Severini, $M D^{3,4}$
}

\author{
Address \\ ${ }^{1}$ Provincial Laboratory for Public Health (ProvLab), Edmonton, Alberta, Canada \\ ${ }^{*}, 2$ Department of Laboratory Medicine and Pathology, University of Alberta, \\ Edmonton, Alberta, Canada \\ Email: Carmen.Charlton@albertahealthservices.ca \\ ${ }^{3}$ Department of Medical Microbiology and Infectious Diseases, University of \\ Manitoba, Winnipeg, MB, Canada \\ ${ }^{4}$ National Microbiology Laboratory, Public Health Agency of Canada, Winnipeg, \\ MB, Canada
}

Published online: 19 0ctober 2016

(C) Springer Science+Business Media New York 2016

This article is part of the Topical Collection on Viral Infections

Keywords Rubella immunity · Rubella serology • Prenatal immunity testing · Rubella antibody levels · Rubella cut off · Waning immunity $\cdot$ Rubella IgM false positives

\section{Opinion statement}

The changing epidemiology of rubella in populations with either low prevalence levels, or where rubella elimination has been achieved, has challenged laboratory diagnostics. This review will discuss the challenges in identification of acute rubella and outline appropriate confirmatory testing, particularly for cases with low pretest probability. Implementation of pre-analytical screening processes can mitigate follow-up testing required to confirm false positive antibody results, and laboratories should consider not accepting requests for testing that do not have appropriate travel or clinical history. The role of laboratory surveillance will be examined, and challenges in determining protective immunity to rubella infection in light of waning rubella antibody levels in vaccinated populations will be explored. Special populations including prenatal women and the prevention of congenital rubella syndrome will be discussed in the context of low prevalence populations.

\section{Introduction}

\section{Viral properties}

Rubella is a small positive sense enveloped RNA virus. Entry into host cells is thought to involve the envelope glycoproteins E2 and/or E1, which facilitate entry via clathrin-mediated endocytosis [1, 2], but the specific cellular receptor has not been yet identified. Rubella is 
the only member in the genus Rubivirus of the Togaviridae family, and shares genetic similarity to the alphaviruses, which includes mosquito-borne viruses such as the Sindbis and Chikungunya virus. Sequence analysis of rubella viruses shows circulating strains differ by up to $8-10 \%$ in their nucleotide sequence $[3,4]$, and are separated into two distinct clades (1 and 2) [3,5], comprised of 12 genotypes $(1 \mathrm{~B}, 1 \mathrm{C}, 1 \mathrm{D}, 1 \mathrm{E}, 1 \mathrm{~F}, 1 \mathrm{G}, 1 \mathrm{H}$, 1I, 1J, 2A, 2B, and 2C) and one provisional genotype (1a) [6]. As some genotypes are geographically restricted, clade and genotype identification can help identify whether a strain is endemically acquired or imported. For example, clade 2 is not currently circulating in North or South America, therefore identification of this clade in the Americas would indicate a case of non-endemic origin [6].

\section{Rubella disease}

Rubella typically causes a mild childhood illness with fever, rash, and lymphadenopathy in the postauricular nodes. Transient polyarthralgia appearing 16-20 days after exposure to the virus, and lasting 3-5 days in duration, can also be observed following acute rubella infections [7]. The characteristic rubelliform rash is distinguished by fine erythematous distinct macules that start on the face and later spread to the trunk. Communicability of the virus begins 5-7 days before the start of symptoms, and can last 3-7 days after symptom resolution. Therefore, home isolation is recommended for 1 week after the disappearance of rash $[7,8]$. While severe complications have been noted following acute rubella infection, including encephalitis and thrombocytopenia, cases are extremely rare.

The primary concern with rubella infection is when it is acquired during pregnancy. Particularly, fetal infection during the first 16 weeks of gestation can result in congenital rubella syndrome (CRS) development. CRS is associated with severe long-term sequelae including micropthalmia, chorioretinitis, deafness, limb aplasia, and cognitive impairments such as microcephaly $[9,10]$. In endemic countries, CRS continues to be reported at high levels. Worldwide, approximately 100,000 cases are estimated per year [11]. Some of these fetal symptoms mirror what have been identified in the current Zika outbreak in Brazil and South America, making identification of CRS increasingly difficult. Worldwide vaccination has resulted in a significant decrease in the incidence of acute rubella and CRS cases [6]. As a result of vaccination programs, the WHO declared rubella and CRS eliminated from the Americas on April 2015 [12•]. Member states of the Pan American Health Organization (PAHO) are required to document elimination by maintaining a highquality case-based surveillance system, and report all imported CRS and rubella cases, including genotype, to the PAHO and the WHO $[13,14]$.

\section{Vaccination and immunity screening}

Prevention of CRS is the primary goal of prenatal programs worldwide. Targeted vaccination to prepubescent girls was shown to decrease the incidence of CRS; however, it was not until the implementation of universal childhood vaccination programs (for both genders) that a significant reduction in the incidence of acute rubella and CRS cases was observed. Meta-analysis of rubella seroprevalence showed maternally acquired immunity was lost in infants by 9 months, and infants were susceptible to infection from 9 months until vaccination [15]. The WHO therefore recommends childhood vaccination with MMR at 9 months in areas with active measles and rubella transmission, which can be delayed until 12 months in areas of low prevalence [16]. A minimum vaccine coverage rate for rubella is approximately $91 \%$ based on an Ro between 6 and 7 (from England, Wales, and West Germany between 1960 and 1970 [17] $)$, and a vaccine failure rate of $5 \%(1-(1 / \mathrm{Ro})=$ $1-(1 / 7)=0.857+0.05=90.7 \%)$. Current coverage rates and vaccination programs are outlined in Table 1.

\title{
Testing for acute rubella and congenital rubella syndrome
}

\author{
Who should be tested?
}

Detection of rubella-specific IgM is recommended by the WHO [13] and the US $\mathrm{CDC}$ [32] as the frontline diagnostic test for surveillance and diagnosis of suspected rubella cases. The WHO requests each participating country to submit the total number of IgM tests performed to evaluate the quality of their surveillance program. The number of IgM tests should exceed 2/100,000 population [33]. IgM is the first class of antibodies produced following a rubella 
Table 1. Select vaccination programs for rubella and relative rates of congenital rubella syndrome (CRS)

\begin{tabular}{|c|c|c|c|c|}
\hline $\begin{array}{l}\text { Institution } \\
\text { or country }\end{array}$ & Target population & Vaccine coverage & Cases of CRS & Reference \\
\hline USA & $\begin{array}{l}\text { Universal childhood immunization } \\
\text { (2 doses: } 12 \text { months and } \\
\text { 4-6 years), since } 1998\end{array}$ & $\begin{array}{l}91.5 \% \text { with } \geq 1 \text { dose } \\
\text { for those } 19-35 \\
\text { months of age }\end{array}$ & $\begin{array}{l}4 \text { Cases (between } \\
2005 \text { and 2011) }\end{array}$ & {$[18,19]$} \\
\hline Canada & $\begin{array}{l}\text { Universal childhood immunization } \\
\text { (2 doses: } 12 \text { months and } \\
\text { 4-6 years), since } 1996\end{array}$ & $\begin{array}{l}89.2 \% \text { with } \geq 1 \text { dose } \\
\text { by } 2 \text { years of age } \\
94.5 \% \text { with } \geq 1 \text { dose } \\
\text { by } 7 \text { years of age }\end{array}$ & $\begin{array}{l}3 \text { Cases (between } \\
2005 \text { and 2014) }\end{array}$ & {$[20,21]$} \\
\hline Australia & $\begin{array}{l}\text { Universal childhood immunization } \\
\text { MMRV (2 doses: } 12 \text { months and } \\
18 \text { months), since July } 2013 \text {, } \\
\text { MMR vaccination since } 1993\end{array}$ & $\begin{array}{c}>80 \% \text { with } \geq 1 \text { dose } \\
\text { by } 2 \text { years of age }\end{array}$ & $\begin{array}{l}0.3 \text { per } 100,000 \\
\text { between } 2003 \text { and } \\
2014\end{array}$ & [22-24] \\
\hline Germany & $\begin{array}{l}\text { Universal childhood vaccination } \\
\text { MMRV ( } 2 \text { doses: } 11-14 \text { months } \\
\text { and } 15-23 \text { months), since } 2009\end{array}$ & $\begin{array}{c}>90 \% \text { across all } \\
\text { birth cohorts }\end{array}$ & $\begin{array}{l}1.1 \text { per } 1,000,000 \\
\text { in } 2015\end{array}$ & {$[25-27]$} \\
\hline UK & $\begin{array}{l}\text { Universal childhood vaccination } \\
\text { (2 doses: } 12-13 \text { months and } \\
\text { 3-4 years of age), vaccine } \\
\text { implemented } 1988\end{array}$ & $\begin{array}{l}91.5 \% \text { with } \geq 1 \text { dose } \\
\text { by } 2 \text { years of age } \\
95.2 \% \text { with } \geq 1 \text { dose } \\
\text { by } 5 \text { years of age }\end{array}$ & 1 case in 2014 & {$[28,29]$} \\
\hline China & $\begin{array}{l}\text { Universal childhood immunization } \\
\text { ( } 2 \text { doses: } 8 \text { months and 18-24 } \\
\text { months of age), vaccine } \\
\text { implemented } 2005\end{array}$ & $\begin{array}{l}70 \% \text { with } \geq 1 \text { dose } \\
\text { by } 9 \text { years of age }\end{array}$ & $\begin{array}{l}9.32 \text { per } 100,000 \\
\text { ( } 167 \text { cases) in } \\
2011 \\
0.87 \text { and } 0.59 \text { per } \\
100,000 \text { in } 2014 \\
\text { and } 15 \text { respectively }\end{array}$ & {$[30,31]$} \\
\hline
\end{tabular}

infection and are detectable in virtually $100 \%$ of cases $4-28$ days after rash onset [34], and may persist for several months thereafter [35]. IgM antibodies are neutralizing [36-38], and their rapid production is an effective device to limit the spread of the virus and reduce viremia.

Detection of IgM is a very sensitive and rapid way to confirm a suspected rubella case, but its specificity is not absolute. Although the best commercial enzyme immunoassays (EIA) kits for rubella IgM have excellent performance, with a specificity of around $95 \%$ [39-42], false positive results are always possible. In low prevalence or elimination settings, the positive predictive value of the rubella IgM assay drops virtually to zero. In these scenarios, all IgM positive results are likely to be false positives in the absence of a definite exposure history [43]. In the Americas, where rubella and CRS were declared eliminated in April 2015, detection of rubella IgM antibodies is indicated in cases with probable exposure to rubella, or with history of travel to endemic areas. In these settings, confirmation of an IgM positive result by direct detection of the rubella virus from nasopharyngeal or throat swabs, urine, and/or serum is recommended (see molecular diagnostics section below).

Immunization with rubella-containing vaccines produces a rubellaspecific IgM response, which is not linked to rubella infection. It is not possible to distinguish between vaccine-induced and naturally induced 
rubella antibodies and therefore serology testing for rubella within 68 weeks after rubella immunization is problematic.

False positive rubella IgM results can occur following infection with other viruses, namely parvovirus B19, Epstein-Barr virus, cytomegalovirus, and measles, which all can produce cross-reactive IgM [44-48]. The presence of rheumatoid factor (an anti-human immunoglobulin autoantibody most commonly of the IgM class) is also a common source of interference in IgM assays [49-51]. Rheumatoid factor is found in $10 \%$ of the population, even without disease symptoms [49], and it can be induced by a number of bacterial and viral infections [51, 52]. Indirect EIA IgM kits are well validated [39, 41, 53] and are most commonly used in WHO-accredited laboratories [54••]; however, for maximum specificity, they require a pretreatment step to remove rheumatoid factor and other IgG antibodies that may interfere with the assay. IgM capture EIA kits are also available for rubella IgM testing [39, 40]. They are based on a different principle, which minimizes interference with some non-specific IgMs and specific IgG and may decrease the level of false positive results [41]. It is good practice to repeat equivocal or contradictory rubella IgM results using EIA kits based on different methodologies [50].

False positive rubella IgM results are particularly troublesome during pregnancy, because they may lead to the decision to abort the fetus. Rubella infection in the first 12 weeks of pregnancy carries a $90 \%$ risk of congenital abnormalities that constitute congenital rubella syndrome (CRS). The most common source for false IgM positive results in pregnancy is the erroneous request of rubella IgM during, as part of routine prenatal testing, or as part of the diagnostic work-up for a flu-like illness with or without rash $[43,55]$. Pregnant women should therefore not be tested for rubella IgM unless there is a history of contact with a laboratory-confirmed rubella case, or history of travel to endemic areas during pregnancy. Clinical and reference laboratories in countries of very low rubella incidence should remind physicians of the futility of ordering a rubella IgM test without credible history of exposure.

\section{Confirmation of positive rubella IgM results}

Once a positive rubella IgM result has been obtained, further testing to confirm or exclude rubella may be necessary. Nasopharyngeal and urine samples should be tested for viral detection by PCR; however, beyond 7 days after rash onset the sensitivity of detection of rubella virus drops dramatically. Therefore, in the absence of appropriate travel history, or appearance of a rash, a negative rubella PCR cannot exclude a recent infection. IgG seroconversion, or a fourfold increase of IgG titers, can also be used to reliably confirm recent rubella infection in the presence of rubella IgM antibodies. Acute (within 7 days post-rash) and convalescent (at least 20 days after rash onset) samples for IgG are required.

An informative and specific laboratory test is the measurement of IgG avidity, i.e., the strength with which IgG antibodies bind to their specific target. During primary infection, IgG antibodies undergo a process of maturation, during which $\mathrm{B}$ cell clones producing antibodies of higher affinity for their 
specific target are selected [56-58]. As a result, IgG in serum bind more tightly even in the presence of denaturing agents such us urea or diethylamine. Avidity is calculated as a function of percentage of IgG bound in the presence or absence of a denaturing agent, which increases from "low" to "high" within 2 months following rubella infection. Thus, a low avidity rubella IgG combined with a positive rubella IgM, strongly suggests rubella infection occurred within the past 2 months. Conversely, high avidity results indicate a more remote infection, or an anamnestic $\operatorname{IgG}$ response (if there was a rise in IgG titers). Unfortunately, since IgM can sometimes persist past the time of IgG maturation [59], a high avidity result later in pregnancy cannot exclude rubella infection occurred before conception.

In summary, confirmation of a positive IgM result requires extensive additional testing which can be prevented with appropriate pre-analytical processing of samples, specifically, by canceling all rubella IgM requests without appropriate history of illness or exposure, such as those requested as part of a routine serological screening of a pregnant woman. More information and references can be found in the WHO "Manual for the laboratory diagnosis of

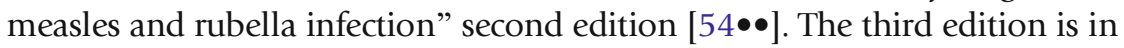
preparation.

Detection of rubella virus in suspected cases can be used to confirm a case of rubella and can resolve any uncertainty that may remain after serological testing. Detection of the rubella virus is performed using molecular methods, especially real-time RT-PCR, for which several well-validated assays are available [60-62]. Culture isolation and direct immunofluorescence are no longer in general use, being supplanted by the faster and more sensitive molecular tests.

While the molecular detection and the interpretation of results are rarely problematic for the modern clinical microbiology laboratory, timing of specimen collection is crucial to ensure the sensitivity of detection [55]. Nasopharyngeal (NP) swabs or urine are the specimens of choice, and should be collected as soon as possible after rash onset and, for optimal

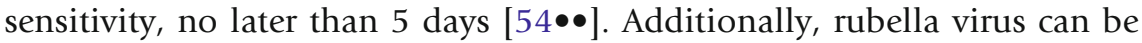
detected in serum, but with lower sensitivity compared to NP swabs or urine specimens. Like all PCR-based methods, a negative result does not exclude the presence of a recent infection, especially if a rash is not detected, and the date of exposure is not known.

Vaccine strains of rubella virus can be detected in urine or NP swabs up to 28 days after immunization [63], and this should be considered when interpreting positive RT-PCR results in recently vaccinated individuals. Genotyping can be used to differentiate between a wild-type infection and a vaccine-derived PCR positive, and is performed by RT-PCR amplification and sequencing of the WHO standardized 739 nucleotide region of the E1 envelope protein gene [64]. PAHO requests all member states to genotype isolates and submit the sequence of all sporadic cases or outbreaks [13] to the WHO worldwide database (RubeNS). Sequence comparisons against the RubeNS can help track imported infections and document elimination. 
It is therefore of paramount importance to obtain a timely NPS or urine specimen for molecular analysis in every suspected case or rubella.

Recommendations

- A positive rubella IgM result is strongly indicative of a recent rubella infection in high endemicity areas following probable exposure, or in low incidence/elimination areas with a history of travel to endemic rubella areas or exposure to a laboratory confirmed case.

- In very low incidence settings, screening of pregnant women for rubella IgM without history of exposure should be avoided, since virtually all positive results will be false positives.

- In these cases, positive IgM results should be confirmed with alternative testing methods including IgM retesting, rubella virus detection by RTPCR, IgG seroconversion, and IgG avidity testing.

- Appropriate pre-analytical consideration is needed for rubella IgM, as laboratory testing may not be able to confirm or exclude a positive or equivocal rubella IgM result in the absence of a clear exposure history.

- Molecular testing (RT-PCR) will confirm a suspected case of rubella, but not exclude it, if precise history of exposure or rash is not available.

\section{Acute rubella and CRS surveillance}

The WHO recommends rubella surveillance in all countries that have implemented rubella-containing vaccination for their populations [13]. As of 2015, 703 laboratories involved in the detection of rubella and CRS in 199 countries participated in the WHO Global Measles and Rubella Laboratory Network (GMRLN) [65]. Countries that are close to, or have achieved, elimination are recommended to monitor for all cases of febrile and rash based illnesses, while countries that have active circulation of rubella should monitor for cases of congenital infection.

Rubella elimination was achieved in 2004 in the USA and 2005 in Canada, respectively. Rubella and CRS were officially declared eliminated from the whole region of the Americas in April 2015 [12•]. To maintain elimination, PAHO has requested each country to collect and report on three key indicators that must be fulfilled: (1) maintenance of high vaccine coverage, including hard to reach populations (where coverage rates of approximately $91 \%$ are required to maintain herd immunity), (2) maintenance and strengthening of surveillance systems to detect all acute rubella and CRS cases, and (3) to promote and support rapid response to outbreaks [14].

Nationwide surveillance for acute and congenital rubella in Canada is primarily an active system, where acute and CRS cases are submitted to the Public Health Agency of Canada by each province and territory on a weekly basis. Epidemiological data including patient demographic information, vaccination status, and travel history are linked with laboratory 
Table 2. Surveillance systems for acute rubella and CRS cases

\begin{tabular}{|c|c|c|c|c|}
\hline Surveillance system & Location & Active or passive? & Cases & $\begin{array}{l}\text { Publically } \\
\text { available } \\
\text { data sources }\end{array}$ \\
\hline $\begin{array}{l}\text { Canadian Measles/ } \\
\text { Rubella Surveillance } \\
\text { System (CMRSS) }\end{array}$ & Canada & $\begin{array}{l}\text { Active/passive*, } \\
\text { since } 1998\end{array}$ & Acute and CRS & {$[66]$} \\
\hline $\begin{array}{l}\text { MARS (measles and } \\
\text { rubella surveillance) }\end{array}$ & $\begin{array}{l}\text { Canada (BC, Alberta, } \\
\text { Newfoundland, } \\
\text { and Labrador) }\end{array}$ & Active, since 2011 & Acute and CRS & {$[66]$} \\
\hline $\begin{array}{l}\text { Centers for Disease } \\
\text { Control (CDC) }\end{array}$ & USA & $\begin{array}{l}\text { Active/passive*, } \\
\text { since } 1966\end{array}$ & Acute and CRS & {$[67,68]$} \\
\hline $\begin{array}{l}\text { European Center for } \\
\text { Disease Prevention } \\
\text { and Control (ECDC) }\end{array}$ & $\begin{array}{l}28 \text { member states } \\
\text { (within the European } \\
\text { Union (EU) and } \\
\text { European Economic } \\
\text { Area (EEA)) }\end{array}$ & $\begin{array}{l}\text { Active/passive* } \\
\text { since } 2012\end{array}$ & Acute and CRS & [69] \\
\hline $\begin{array}{l}\text { Australian Paediatric } \\
\text { Surveillance Unit } \\
\text { (APSU) }\end{array}$ & Australia & $\begin{array}{l}\text { Active/passive*, } \\
\text { since } 2004\end{array}$ & Acute and CRS & {$[70]$} \\
\hline $\begin{array}{l}\text { National } \\
\text { Epidemiological } \\
\text { Surveillance of } \\
\text { Infectious } \\
\text { Diseases (NESID) }\end{array}$ & Japan & $\begin{array}{l}\text { Active/passive*, } \\
\text { since } 1999\end{array}$ & Acute and CRS & {$[71,72]$} \\
\hline $\begin{array}{l}\text { World Health } \\
\text { Organization (WHO) }\end{array}$ & $\begin{array}{l}\text { Global Measles and } \\
\text { Rubella Laboratory } \\
\text { Network (GMRLN); } \\
\text { includes SEAR, } \\
\text { AMR, EUR, WPR, } \\
\text { EMR, and AFR }\end{array}$ & $\begin{array}{l}\text { Active/passive*, } \\
\text { implementation } \\
\text { dates vary by } \\
\text { region }\end{array}$ & $\begin{array}{l}\text { Acute and CRS and } \\
\text { febrile illness for } \\
\text { countries who have } \\
\text { not achieved } \\
\text { elimination }\end{array}$ & [73] \\
\hline
\end{tabular}

data from the National Microbiology Laboratory when specimens are submitted for further work-up. Likewise, the USA legislates that all acute and CRS cases be reported to their respective state public health laboratories, and other international organizations regularly publish acute rubella and CRS cases (see Table 2 for outline of different surveillance methods); however, like Canada, these systems rely on accurate and timely reporting from healthcare workers, schools, and laboratories, among others.

A fully active surveillance pilot project was implemented in Canada in 2011, to track real-time laboratory data in three jurisdictions (BC, Alberta and Newfoundland, and Labrador). All patient specimens submitted for rubella or measles testing are reported via the local and provincial laboratories to the PAHO where cases are identified and tracked through a web-based system. This automatic reporting system captures all samples tested for rubella, and offers real-time coordination between laboratory and epidemiology data. Detection of acute rubella and CRS cases is however still dependent on clinical suspicion 
and appropriate laboratory testing. A stronger link to epidemiological data and laboratory data is therefore needed globally to fully understand the disease burden of rubella, and to overcome challenges with accurate and timely reporting of results [65].

\section{Testing for protective immunity to rubella}

\section{Who should be tested?}

Detection of rubella-specific IgG is recommended for specific populations, including prenatal women by the WHO [12•] and the US CDC [14] as a preventative measure for development of fetal CRS. From a public health perspective, serosurveys for rubella IgG is recommended to understand the overall level of protection across populations, which can be used to target vaccine uptake to at risk populations. Particularly for health care workers, use of rubella IgG testing following exposure to a case patient may help to identify risk of infection.

In areas of low prevalence, rubella antibody screening of prenatal women is often included in the routine screening programs. Integrated screening and vaccination programs offer postnatal vaccination to all women with antibodies below the level that is considered to be protective. On April 1, 2016, the UK became the first country to end rubella immunity screening in pregnant women. The UK achieved rubella elimination due to high MMR vaccine coverage (95.2\% coverage by the age of 5 years [29], which is greater than the required $91 \%$ coverage estimated for herd immunity). Because rubella screening identifies women who may not be protected from rubella infection, but vaccine is contraindicated during pregnancy, no preventative action can therefore be taken on the initial screening result. The UK therefore decided that vaccination prior to pregnancy was more advantageous than upfront screening and targeted postnatal vaccination.

In countries that have achieved elimination, possible inaccuracies in IgG screening results have been observed, including waning immunity (discussed in detail below). As countries decide how to handle the changing epidemiology of rubella screening results, screening strategies will likely diversify as countries identify the most effective health care strategies for their populations.

\section{Neutralizing versus total antibody}

Neutralizing antibody testing is considered the most reliable indicator of protective immunity, as it can detect antibodies to E1 and E2 rubella envelope proteins [74]. Cell cultures are challenged with live rubella virus in the presence, or absence, of patient serum. The viability of cell monolayers is therefore a direct measure of the ability of serum antibodies to block infection of rubella virus [75], and results can be used to effectively correlate levels of immunity. It is important to note that neutralization assays were used to determine what level of antibody constitutes a protective immune response. The earliest vaccine trials used neutralization testing to correlate with clinical immunity, and these studies were used to develop the currently used cut offs for rubella IgG levels [76].

Due to the variability and high labor cost of the assay, neutralization antibody testing generally fell out of favor as a routine screening test, and 
was replaced most recently by enzyme immunoassays (EIA) [74]. The high throughput design and relative low cost of EIAs compared to the neutralization antibody assay facilitated incorporation into the routine clinical laboratory. Many commercial assays are now available for use in the clinical laboratory, and use a range of detection systems (including chemiluminescence, electrochemiluminescence, and immunofluorescence) and rubella antigens (including viral lysates, purified proteins, and recombinant protein). Because the rubella antigens used by manufactures differs, variability in the amount of rubella-specific IgG detected is often observed when identical samples are tested between different platforms [77-81, 82•]. While EIAs detect total levels of rubella-specific IgG, it is not a direct measure of the level of protection those antibodies would provide upon challenge with rubella virus (compared to the neutralization test, not all rubella-specific IgG will provide protection from

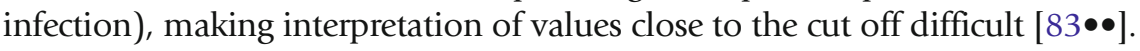

Rubella IgG cut offs

The Rubella Subcommittee of the National Committee on Clinical Laboratory Standards (NCCLS) first established a cut off of $>15 \mathrm{IU} / \mathrm{ml}$ rubella antibodies in 1985 [76]. Samples from patients testing $>15 \mathrm{IU} / \mathrm{ml}$ were considered immune, and those testing $<15 \mathrm{IU} / \mathrm{ml}$ were considered susceptible to infection. In 1992, this cut off was revised to $>10 \mathrm{IU} / \mathrm{ml}$ following additional clinical and epidemiological studies [84-87], showing that a secondary immune response was elicited by patients with antibody levels $<15 \mathrm{IU} / \mathrm{ml}$ following challenge with live-attenuated vaccine, or reinfection [88]. Using an antibody titer as a marker of immunity presents a number of diagnostic challenges: first, the numerical antibody value is known to vary between testing assays [82•], which may result in different interpretations when the same sample is tested on multiple assays. In fact, we have recently shown that a $30 \%$ difference in titer can be seen between assays manufactured by the same company [89]. Secondly, using a quantitative titer, rather than a positive or negative qualitative value, challenges the limits of serology testing. This creates an assay where positive values are within one $\mathrm{IU} / \mathrm{ml}$ from negative values, and no statistical difference (i.e., a difference of 2 standard deviations) separates negative from positive results. Mathematical modeling of a large prenatal population showed a natural distribution of true negative values, and true positive values, with a difference between the means representing a 126-fold change in IgG levels [90].

How to interpret waning immunity in populations with universal vaccination

In countries where universal vaccination was adopted greater than 10 years ago, a significant decline in total rubella IgG antibody levels has been observed [81, 90-92]. Particularly in younger age cohorts, a growing proportion have antibody levels below the level considered to be protective [90]. While the cases of acute rubella and CRS have not increased over the same time frame [91, 93, 94] (highlighting the effectiveness of the vaccine program), it is difficult to accurately assess the level of protective immunity in these populations. The reason for the reduction in rubella-specific antibodies in vaccinated individuals, compared to those who acquired immunity via natural infection, is potentially twofold: longevity of antibodies and decreased circulation of wild type virus. 
Longevity studies using the tetravalent vaccine have shown $100 \%$ seropositivity for rubella 3 years post-vaccination [95]. The time since vaccination appears to be inversely proportional however, as 12 years after immunization with the trivalent vaccine, $69 \%$ of children were either seronegative, or had low levels of rubella antibody, whereas only $7 \%$ had low or no antibodies 1 month after vaccination [96]. Revaccination of women with no, or low, rubella antibody levels resulted in IgG levels $>15 \mathrm{IU} / \mathrm{ml}$ in $55.8 \%$ of cases after a mean of 1.1 years since time of vaccination [90], or in $26 \%$ of cases after 5 years [97]. The timing of vaccination in these populations may also play a role in the longevity of rubella IgG levels. As seen in Table 1, the first immunization dose is typically given at 1 year of age; however, in 2005, China adopted an accelerated vaccine schedule with doses at 8 and 18 months. Antibody persistence was shown for the duration of the study (10 months) and participants in the trial group (vaccine at 8 and 18 months) had statistically higher total rubella IgG antibody titers compared to the control group (vaccine at 12 and 22 months); however, both levels were well above the $>10 \mathrm{IU} / \mathrm{ml}$ cutoff of positivity [98]. As these updated vaccination schedules were introduced in China in 2005, it will be interesting to examine the presence of antibodies as this cohort ages, and whether the longevity of antibody titers is maintained into adulthood.

A compounding factor to the observed decline in antibody levels is the reduction of circulating wild-type virus due to herd immunity. As more people are vaccinated, the number of acute rubella infections decreases (as evidenced in the decreased case rates of rubella and CRS) [90, 91, 93, 94]. Thus, the number of people who would have experienced a boost to their immunity from postvaccine exposure to the virus has also decreased. In Israel, decreased IgG levels observed in younger age cohorts were attributed to lack of circulating wild-type virus and lower vaccination coverage [99]. Those born in 1977-78 had a seroprevalence of $95.6 \%$ compared to those born in 1988-89 who had $85.7 \%$ seroprevalence for measles, which was shown to correlate with the seroprevalence for rubella [99].

\section{Recommendations}

- A positive rubella IgG is a strong indicator of protective immunity, and patients can generally be considered protected from infection when levels are $>10 \mathrm{IU} / \mathrm{ml}$.

- A positive rubella IgG result $<10 \mathrm{IU} / \mathrm{ml}$ suggests that a patient was previously vaccinated or exposed to rubella, but may be susceptible to infection. However in areas with low prevalence/elimination, antibody levels below $10 \mathrm{IU} / \mathrm{ml}$ may still be protective, as herd immunity is maintained despite waning antibody levels.

- Prenatal screening programs should consider the incidence of rubella in their population and overall vaccination coverage to determine the best screening strategies.

\section{Conclusions}

The changing epidemiology of rubella prevalence has challenged laboratory diagnostics. Low disease prevalence can cause uncertainty with a high number 
of false positive results, and waning antibody levels in vaccinated populations make it difficult to determine true protective immunity. Understanding the pretest probability and limiting IgM testing to only cases with a clinical history of rubella-like infection can decrease the number of false positive results, and subsequent follow-up testing. Re-evaluation of when to use rubella IgG as a screen for protective immunity, particularly in populations where rubella has been declared eliminated may decrease patient anxiety and physician uncertainty when results are below the level that is considered protective.

\section{Compliance with Ethical Standards}

\section{Conflict of Interest}

Dr. Charlton and Dr. Severini declare that they have no conflicts of interest.

\section{Human and Animal Rights and Informed Consent}

This article does not contain any studies with human or animal subjects performed by any of the authors.

\section{References and recommended reading}

Papers of particular interest, published recently, have been highlighted as:

- Of importance

$\bullet \quad$ Of major importance

1. Kee SH et al. Effects of endocytosis inhibitory drugs on rubella virus entry into VeroE6 cells. Microbiol Immunol. 2004;48(11):823-9.

2. Lee JY, Bowden DS. Rubella virus replication and links to teratogenicity. Clin Microbiol Rev. 2000;13(4):57187.

3. Katow $\mathrm{S}$ et al. Molecular epidemiology of rubella by nucleotide sequences of the rubella virus E1 gene in three East Asian countries. J Infect Dis. 1997;176(3):602-16.

4. Zheng DP et al. Global distribution of rubella virus genotypes. Emerg Infect Dis. 2003;9(12):1523-30.

5. Frey TK et al. Molecular analysis of rubella virus epidemiology across three continents, North America, Europe, and Asia, 1961-1997. J Infect Dis. 1998;178(3):642-50.

6. World Health Organization. Wkly Epidemiol Rec Relevé épidémiologique hebdomadaire. 2013;88:33748.

7. Banatvala JE, Brown DW. Rubella. Lancet. 2004;363(9415):1127-37.

8. 316.651px, d.d.-c.-w.s.l., et al., Manual for the Surveillance of Vaccine-Preventable Diseases. 5th ed. Vol. Rubella: Chapter 14-1. 2012.

9. Koklu E et al. Blueberry muffin syndrome owing to congenital rubella: case report. Ann Trop Paediatr. 2006;26(2):149-51.
10. Centers for Disease Control and Prevention. Revised ACIP recommendation for avoiding pregnancy after receiving a rubella-containing vaccine. MMWR Morb Mortal Wkly Rep. 2001;50(49):1117.

11. Robertson SE et al. Rubella and congenital rubella syndrome: global update. Rev Panam Salud Publica. 2003;14(5):306-15.

12. Anonymous, International expert committee declares rubella eliminated from the region of the Americas. Immunization Newsletter - Pan American Health Organization, 2015;37(2):1.

In 2015, the Americas officially declared rubella eliminated from the population. This paper outlines the steps taken to achieve rubella elimination, and how elimination was documented.

13. World Health Organization. Rubella and congenital rubella syndrome: WHO-recommended Standards for Surveillance of Selected Vaccine-Preventable Diseases. 2008;35-39.

14. Anonymous, Plan of Action for the Documentation and Verification of Measles, Rubella, and Congenital Rubella Syndrome Elimination in the Region of the Americas. 2011.

15. Dimech W, Mulders MN. A review of testing used in seroprevalence studies on measles and rubella. Vaccine. 2016;34(35):4119-22. 
16. World Health Organization. Rubella vaccines: WHO position paper. Wkly Epidemiol Rec Relevé épidémiologique hebdomadaire.

2011;29(86):301-16.

17. Anderson RM. In: May RM, editor. Infectious diseases of humans: dynamics and control. Oxford: Oxford University Press; 1991.

18. National and Immunization Survey (NIS). NIH Data Table. 2014; Available from: textautospace:none">http://www.cdc.gov/vaccines/imzmanagers/coverage/nis/child/data/tables2014.html.

19. Watson JC et al. Measles, mumps, and rubella-vaccine use and strategies for elimination of measles, rubella, and congenital rubella syndrome and control of mumps: recommendations of the Advisory Committee on Immunization Practices (ACIP). MMWR Recomm Rep. 1998;47(RR-8):1--57.

20. Public Health Agency of Canada. Vaccine Coverage in Canadian Children: Results from the 2013 childhood National Immunization Coverage Survey. 2013; Available from: http://healthycanadians.gc.ca/ publications/healthy-living-vie-saine/immunizationcoverage-children-2013-couverture-vaccinale-enfants/ index-eng.php?_ga=1.248134471.173192881. 1465334943-a3c2.

21. Immunize Canada. Measles. 2016; Available from: mso-bidi-language:AR-SA">http://www.immunize.ca/ en/diseases-vaccines/measles.aspx.

22. Sullivan EM, Burgess MA, Forrest JM. The epidemiology of rubella and congenital rubella in Australia, 1992 to 1997. Commun Dis Intell. 1999;23(8):209-14.

23. Immunise Australia Program. Measles Mumps Rubella Varicella vaccine information for health professionals. 2013; Available from: http://www.immunise.health. gov.au/internet/immunise/publishing.nsf/Content/ IT0167-cnt/\$File/final-mmrv-provider-booklet.pdf.

24. Gidding HF, Burgess MA, Kempe AE. A short history of vaccination in Australia. Med J Aust. 2001;174(1):3740.

25. Vaccine-preventable Diseases and Immunization Programme WHO Regional Office for Europe. WHO EpiData. 2016; Available from: http://www.euro.who. int/_data/assets/pdf_file/0014/312053/EpiDatamonthly-summary-1.pdf?ua=1.

26. Rieck $\mathrm{T}$ et al. Vaccination coverage among children in Germany estimated by analysis of health insurance claims data. Hum Vaccin Immunother. 2014;10(2):476-84.

27. Wiese-Posselt, M. and W. Hellenbrand, Changes to the varicella and pertussis immunisation schedule in Germany 2009: background, rationale and implementation. Euro Surveill, 2010; 15(16).

28. Public Health England. Health Protection Report, weekly report. 28 November 2014; Available from: http://www.gov.uk/government/uploads/system/ uploads/attachment_data/file/382399/hpr4514.pdf.

29. Public Health England, Quarterly vaccination coverage statistics for children aged up to 5 years in the UK
(COVER Programme): January to March 2016. Health Protection Report, Weekly Report, 2016. 10(20).

30. World Health Organization Western Pacific Region. Measles-Rubella Bulletin. July 2016; 10:7:[Available from: http://www.wpro.who.int/immunization/ documents/measles_rubella_bulletin/en/.

31. Wang $Z$ et al. Difficulties in eliminating measles and controlling rubella and mumps: a cross-sectional study of a first measles and rubella vaccination and a second measles, mumps, and rubella vaccination. PLoS One. 2014;9(2):e89361.

32. Centers for Disease Control and Prevention, Rubella German Measles 2013 Case Definition. National Notifiable Diseases Surveillance System (NNDSS), 2013. 12-ID-09.

33. Castillo-Solorzano $\mathrm{C}$ et al. Guidelines for the documentation and verification of measles, rubella, and congenital rubella syndrome elimination in the region of the Americas. J Infect Dis. 2011;204 Suppl 2:S683.

34. Cordoba P et al. Kinetics of rubella-specific IgM antibody response in postnatal rubella infection. J Virol Methods. 1991;34(1):37.

35. Thomas HI et al. Persistence of specific IgM and low avidity specific IgG1 following primary rubella. J Virol Methods. 1992;39(1-2):149.

36. Skountzou I et al. Influenza virus-specific neutralizing IgM antibodies persist for a lifetime. Clin Vaccine Immunol: CVI. 2014;21(11):1481.

37. Doerr HW, Gross G, Schmitz H. Neutralizing serum IgM antibodies in infections with Herpes simplex virus hominis. Med Microbiol Immunol. 1976;162(3-

4):183.

38. Diamond MS et al. A critical role for induced IgM in the protection against West Nile virus infection. J Exp Med. 2003;198(12):1853.

39. Tipples GA et al. Evaluation of rubella IgM enzyme immunoassays. J Clin Virol: Off Publ Pan Am Soc Clin Virol. 2004;30(3):233.

40. Eichler R et al. Evaluation of the new ARCHITECT Rubella IgM assay. J Clin Virol: Off Publ Pan Am Soc Clin Virol. 2007;39(3):182.

41. Dimech $\mathrm{W}$ et al. Evaluation of three immunoassays used for detection of anti-rubella virus immunoglobulin $\mathrm{M}$ antibodies. Clin Diagn Lab Immunol. 2005;12(9):1104.

42. Portella G, Galli C, R.C.e. Multicenter Italian Group for Hospital To. Multicentric evaluation of two chemiluminescent immunoassays for IgG and IgM antibodies towards Rubella virus. J Clin Virol: Off Publ Pan Am Soc Clin Virol. 2010;49(2):105.

43. Best JM et al. Interpretation of rubella serology in pregnancy-pitfalls and problems. BMJ (Clinical research ed). 2002;325(7356):147.

44. Kurtz JB, Anderson MJ. Cross-reactions in rubella and parvovirus specific IgM tests. Lancet (London, England). 1985;2(8468):1356.

45. Cohen BJ, Supran EM. IgM serology for rubella and human parvovirus B19. Lancet (London, England). 1987;1(8529):393. 
46. Donovan SM. False-positive results of an enzyme immunoassay for rubella IgM in a case of measles. Clin Infect Dis: Off Publ Infect Dis Soc Am. 1997;24(2):271.

47. Jensen IP, Vestergaard BF. Assessment of the specificity of a commercial human parvovirus B19 IgM assay. Clin Diagn Virol. 1997;7(3):133.

48. Thomas HI et al. Simultaneous IgM reactivity by EIA against more than one virus in measles, parvovirus B19 and rubella infection. J Clin Virol: Off Publ Pan Am Soc Clin Virol. 1999;14(2):107.

49. Marks V. False-positive immunoassay results: a multicenter survey of erroneous immunoassay results from assays of 74 analytes in 10 donors from 66 laboratories in seven countries. Clin Chem. 2002;48(11):2008.

50. Woods CR. False-positive results for immunoglobulin $\mathrm{M}$ serologic results: explanations and examples. J Pediatr Infect Dis Soc. 2013;2(1):87.

51. Meurman OH, Ziola BR. IgM-class rheumatoid factor interference in the solid-phase radioimmunoassay of rubella-specific IgM antibodies. J Clin Pathol. 1978;31(5):483.

52. Williams RC. Rheumatoid factors in subacute bacterial endocarditis and other infectious diseases. Scand J Rheumatol Suppl. 1988;75:300.

53. Vijaylakshmi P et al. Evaluation of a commercial rubella IgM assay for use on oral fluid samples for diagnosis and surveillance of congenital rubella syndrome and postnatal rubella. J Clin Virol: Off Publ Pan Am Soc Clin Virol. 2006;37(4):265.

54.• World Health Organization, Laboratory diagnosis of measles and rubella. Manual for the laboratory diagnosis of measles and rubella infection, 2007. WHO/ IVB/07.01: p. 41.

The recommendations outlined in this manual are essential for accurate diagnosis of rubella infection.

55. Tipples GA. Rubella diagnostic issues in Canada. The Journal of infectious diseases. 2011;204 Suppl 2:S659.

56. Hedman K, Rousseau SA. Measurement of avidity of specific IgG for verification of recent primary rubella. J Med Virol. 1989;27(4):288.

57. Enders G, Knotek F. Rubella IgG total antibody avidity and IgG subclass-specific antibody avidity assay and their role in the differentiation between primary rubella and rubella reinfection. Infection.

1989;17(4):218.

58. Kocks C, Rajewsky K. Stable expression and somatic hypermutation of antibody $\mathrm{V}$ regions in B-cell developmental pathways. Annu Rev Immunol. 1989;7:537.

59. Thomas HI et al. Persistent rubella-specific IgM reactivity in the absence of recent primary rubella and rubella reinfection. J Med Virol. 1992;36(3):188.

60. Tipples $\mathrm{G}$, Hiebert J. Detection of measles, mumps, and rubella viruses. Methods Mol Biol (Clifton, NJ).

2011;665:183.

61. Okamoto K et al. Evaluation of sensitivity of TaqMan RT-PCR for rubella virus detection in clinical specimens. J Clin Virol: Off Publ Pan Am Soc Clin Virol. 2016;80:98.
62. Abernathy E et al. Confirmation of rubella within 4 days of rash onset: comparison of rubella virus RNA detection in oral fluid with immunoglobulin $\mathrm{M}$ detection in serum or oral fluid. J Clin Microbiol. 2009;47(1):182.

63. Anonymous, Rubella Prevention - Recommendations of the Immunization Practices Advisory Committee (ACIP). Morbidity and Mortality Weekly Reports, 1990; (39): 1-18.

64. Anonymous, Standardization of the nomenclature for genetic characteristics of wild-type rubella viruses. Weekly Epidemiology Record, 2005; (80): 126-132.

65. Rota, J., Report on the 13th World Health Organization Global Measles and Rubella Laboratory Network Meeting. 2015.

66. Public Health Agency of Canada. Measles and rubella weekly monitoring report. 2016; Available from: http://healthycanadians.gc.ca/diseases-conditionsmaladies-affections/disease-maladie/measlesrougeole/surveillance/measles-rubella-reportsrapports-rougeole-rubeole-eng.php.

67. McLean, H., et al., Manual for the Surveillance of Vaccine-Preventable Diseases. 5th ed. Vol. Rubella: Chapter 14-1. 2012.

68. Centers for Disease Control and Prevention, Epidemiology and Prevention of Vaccine-Preventable Diseases: The pink book. 13 ed. 2015.

69. European Center for Disease Prevention and Control. Measles and rubella monitoring, January 2016. Available from: http://ecdc.europa.eu/en/healthtopics/ rubella/epidemiological-data/Pages/epidemiological_ data.aspx.

70. Australian Government Department of Health. Australian Paediatric Surveillance Unit annual reports. 2014; Available from: http://www.health.gov.au/ internet/main/publishing.nsf/Content/cda-apsuannreps.htm.

71. National Institute of Infectious Diseases. IASR, Rubella and congenital rubella syndrome in Japan, as of June 2015. 2015; Available from: textautospace:none">http://www.nih.go.jp/niid/en/indexe/865-iasr/5806-tpc425.html.

72. Centers for Disease Control and Prevention. Nationwide rubella epidemic_Japan, 2013. MMWR Morb Mortal Wkly Rep. 2013;62(23):457-62.

73. Rota JS et al. Comparison of sequences of the $\mathrm{H}, \mathrm{F}$, and $\mathrm{N}$ coding genes of measles virus vaccine strains. Virus Res. 1994;31(3):317.

74. Cradock-Watson JE. Laboratory diagnosis of rubella: past, present and future. Epidemiol Infect. 1991;107(1):1-15.

75. Brown T, Hambling MH, Ansari BM. Rubellaneutralizing and haemagglutinin-inhibiting antibodies in children of different ages. Br Med J. 1969;4(5678):263-5.

76. National Committee on Clinical Laboratory Standards, Evaluation and Performance Criteria for Multiple Component Test Products Intended for the Detection and Quantification of Rubella IgG Antibody, I/LA6-T, Tentative Guidline. 1985: Wayne, PA. 
77. Vlaspolder F et al. Comparison of immulite with vidas for detection of infection in a low-prevalence population of pregnant women in The Netherlands. Clin Diagn Lab Immunol. 2001;8(3):552-5.

78. Diepersloot RJ et al. Antenatal screening for hepatitis B and antibodies to Toxoplasma gondii and rubella virus: evaluation of two commercial immunoassay systems. Clin Diagn Lab Immunol. 2001;8(4):785-7.

79. Binnicker MJ, Jespersen DJ, Rollins LO. Evaluation of the Bio-Rad BioPlex Measles, Mumps, Rubella, and Varicella-Zoster Virus IgG multiplex bead immunoassay. Clin Vaccine Immunol. 2011;18(9):1524-6.

80. Enders $\mathrm{M}$ et al. Performance of the Elecsys Rubella IgG assay in the diagnostic laboratory setting for assessment of immune status. Clin Vaccine Immunol. 2013;20(3):420-6.

81. Dimech W et al. Investigation into low-level anti-rubella virus IgG results reported by commercial immunoassays. Clin Vaccine Immunol. 2013;20(2):255-61.

82. Huzly D et al. Performance of 14 rubella IgG immunoassays on samples with low positive or negative haemagglutination inhibition results. J Clin Virol. 2016;74:13-8.

This paper describes the variability of rubella assays and highlights the need for standardization of rubella IgG assays.

83.• Dimech W, Grangeot-Keros L, Vauloup-Fellous C. Standardization of assays that detect anti-rubella virus IgG antibodies. Clin Microbiol Rev. 2016;29(1):16374.

This is an excellent review of the current state of rubella diagnostics and explains the difficulties with standardization for IgG testing.

84. Robinson RG et al. Rubella immunity in older children, teenagers, and young adults: a comparison of immunity in those previously immunized with those unimmunized. J Pediatr. 1982;101(2):188-91.

85. O'Shea S, Best JM, Banatvala JE. Viremia, virus excretion, and antibody responses after challenge in volunteers with low levels of antibody to rubella virus. J Infect Dis. 1983;148(4):639-47.

86. Storch GA, Myers N. Latex-agglutination test for rubella antibody: validity of positive results assessed by response to immunization and comparison with other tests. J Infect Dis. 1984;149(3):459-64.
87. Serdula MK et al. Serological response to rubella revaccination. JAMA. 1984;251(15):1974-7.

88. Andrews J et al. Symptomatic rubella re-infection in pregnancy with no evidence of fetal infection. Prenat Diagn. 2004;24(3):227-8.

89. Lai F, Dover D, Charlton CL. Economic impact of switching rubella IgG methodologies to the prenatal Public Health program in Alberta. J Clin Virol. 2016.

90. Lai FY et al. Determining rubella immunity in pregnant Alberta women 2009-2012. Vaccine. 2015;33(5):63541.

91. Davidkin I et al. Persistence of measles, mumps, and rubella antibodies in an MMR-vaccinated cohort: a 20year follow-up. J Infect Dis. 2008;197(7):950-6.

92. Davidkin I et al. Duration of rubella immunity induced by two-dose measles, mumps and rubella (MMR) vaccination. A 15-year follow-up in Finland. Vaccine. 2000;18(27):3106-12.

93. Publich Health Agency of Canada, Elimination of Measles, Rubella and Congenital Rubella Syndrome in Canada - Documentation and Verification Report. 2011, Pan American Health Organization, Regional Office of the World Health Organization. 1-136.

94. Gao Z et al. Models of strategies for control of rubella and congenital rubella syndrome-a 40 year experience from Australia. Vaccine. 2013;31(4):691-7.

95. Knuf $\mathrm{M}$ et al. Antibody persistence for 3 years following two doses of tetravalent measles-mumps-rubellavaricella vaccine in healthy children. Eur J Pediatr. 2012;171(3):463-70.

96. LeBaron CW et al. Persistence of rubella antibodies after 2 doses of measles-mumps-rubella vaccine. J Infect Dis. 2009;200(6):888-99.

97. Francis $\mathrm{BH}$ et al. Rubella screening and vaccination programme at a Melbourne maternity hospital. A fiveyear review. Med J Aust. 1982;1(12):502-4.

98. He H et al. Similar immunogenicity of measlesmumps-rubella (MMR) vaccine administrated at 8 months versus 12 months age in children. Vaccine. 2014;32(31):4001-5.

99. Levine $\mathrm{H}$ et al. Seroprevalence of measles, mumps and rubella among young adults, after 20 years of universal 2 -dose MMR vaccination in Israel. Hum Vaccin Immunother. 2015;11(6):1400-5. 